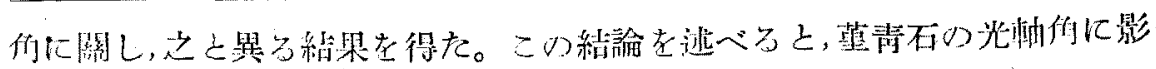

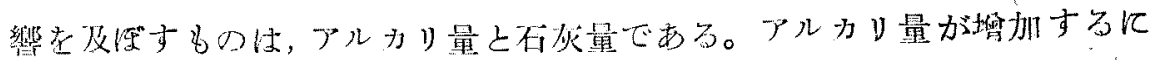

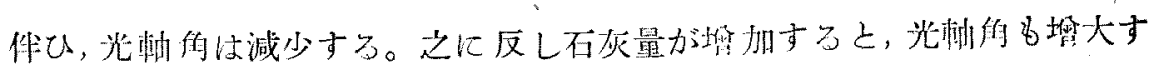

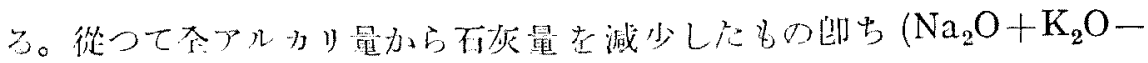

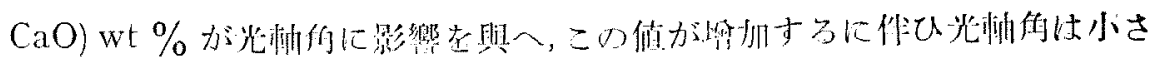

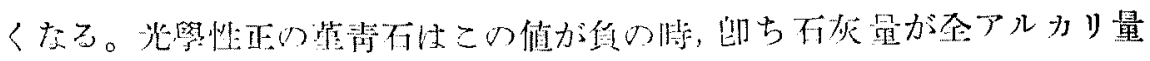
上り多き膨汇見られる11。

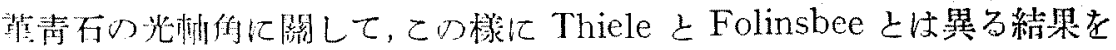

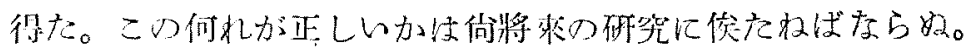

\title{
濠洲及び槑西蘭の金屬碳床 (II)
}

Metallic deposits in Australia and New Zealand (II)

理學搏士 渡 邊 萬 次 郎 (M. Watanabé)

\section{東部蒙洲の地椞の大要}

東部䓑洲心 Queensland, New South Wales, Victoria 三州を包括す

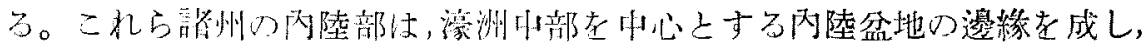

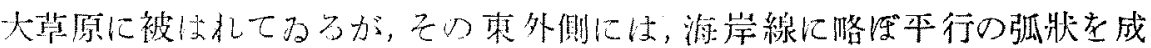
して，一大隆起举が速なり，東方即ち太平洋側からの貿易風在避つてるる。

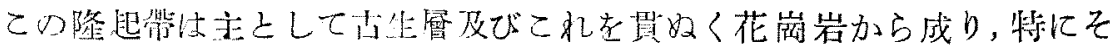
の南部唧ちVictoria 州に热ては，主として奥陶紀及び恐留利亞紀に屬する

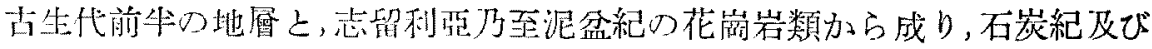

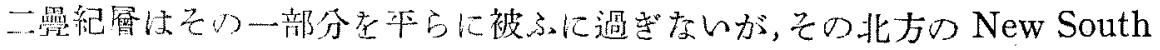

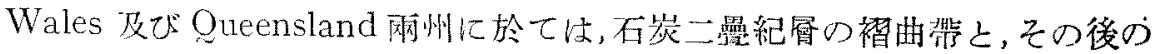

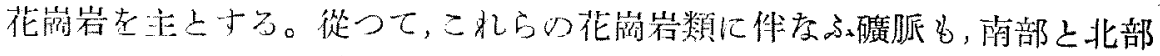

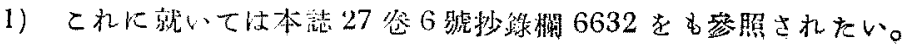




\section{第 八 圖}
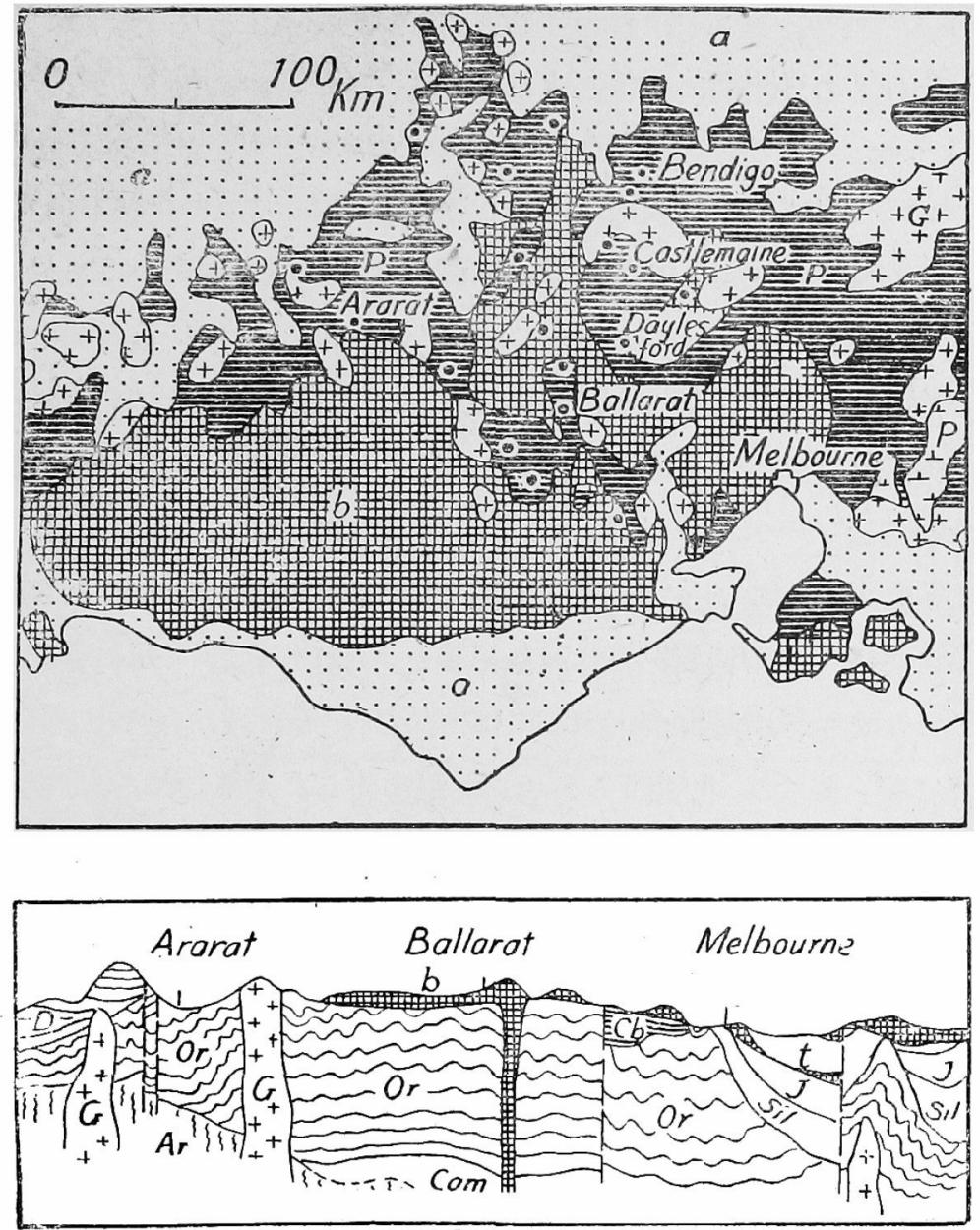

ヴイクトリヤ州全㡾地の地質概圆

(Herman 氏による)

Ar 知原界 $\mathrm{P}$ 古生界 (Or 舆陶系 Sil 志留利婜系 D 泥盆系 $\mathrm{Cb}$ 石炭系) $\mathrm{J}$ 侏羅系 $\mathrm{t}$ 第三系 $\mathrm{a}$ 沖得統 $\mathrm{G}$ 花崗岩猚 $\mathrm{b}$ 玄武岩

ではその時期を異にし，陗部に於ては志留利亞紀万至泥盈紀，北部に於ては 二嘼紀末のものが多い。この外東部各地によ，前記の䚇岩層を被ふ中生層

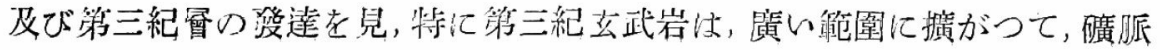




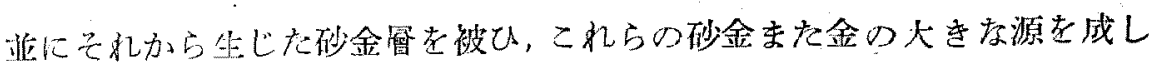
てるる。

次にそれらの冬州別に記溨しよう。

\section{ビクトリヤ州の金磺床}

Victoria 州はI85I 年以來，I939年に至䎤に，72,220,454 金オンス，

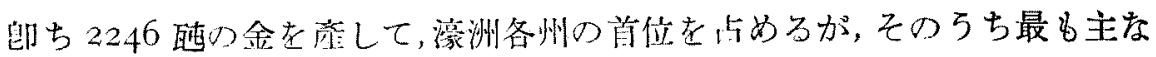
る部分は砂金からで，それらは既に主献部分が探り盡され，その源を成す金

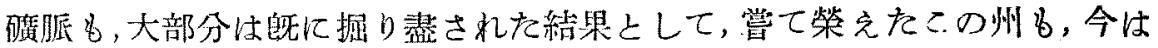

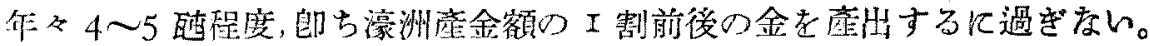

商金他帶はメルボルン市の北に近く,州の中部を東西に貫妨く分水山系 (Great Divide Range) の酉斗部で，主として奥陶紀の褶曲層，一部はそれ

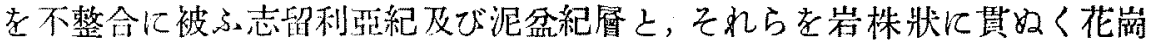

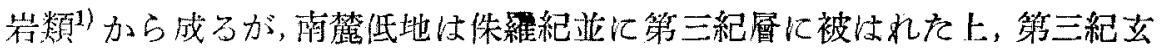
武岩流に廣く被はれ，北㮃卯ち Murray 河に面した平原部は，南方海岸と共 に沖積篔に被はれてるる。從つて金碝林つ露頭は主として山地の中斬部に 限ら机，中に最も主なるものは，Bendigo, Ballarat,Castlemaine, Dayles-

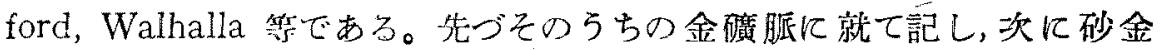
に就て記さう。

Bendigo $^{2)}$ 一名 Sandhurst地方は首府 Melbourne 北西に距る 150 粍，分水山脈つ北背側に位し，地質は北䄪 20 度內外西に偏した曆向を以て， 規则正しく背科，向斜繰返してるる奥陶紀粘板岩及び砂岩の累層から成 り，その西南方に露出してるる花菂岩塊の邊緣からは，I3 粁を隔てっる

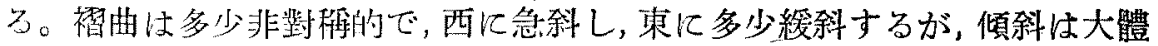

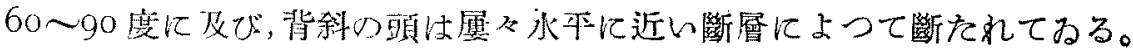

1) W. Lindgren (Am.J.Sci. Ser. IV. Vol. 9, p. 269, 1900) によれば多くは化 峝聞線岩である。

2) J. M. Maclaren, Gold. 1908, 367 370; W. H. Emmons, Gold deposits of the world, 1937, 527 529 等衰照。 


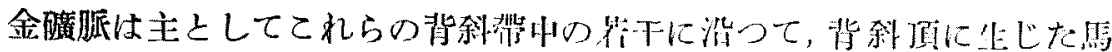
鞍形の間㩐老充たした石英脈で, 所謂鞍肤磺脈 (Saddle reef) 在成し，北斜 の延長に沿万て数百米乃至数十料，頂上部では厚さ（上下）最大 30 米，その 网翼 (legs) に向つて厚さを減じ，上下概双200米以以内て尖減するが，屚

第九圖
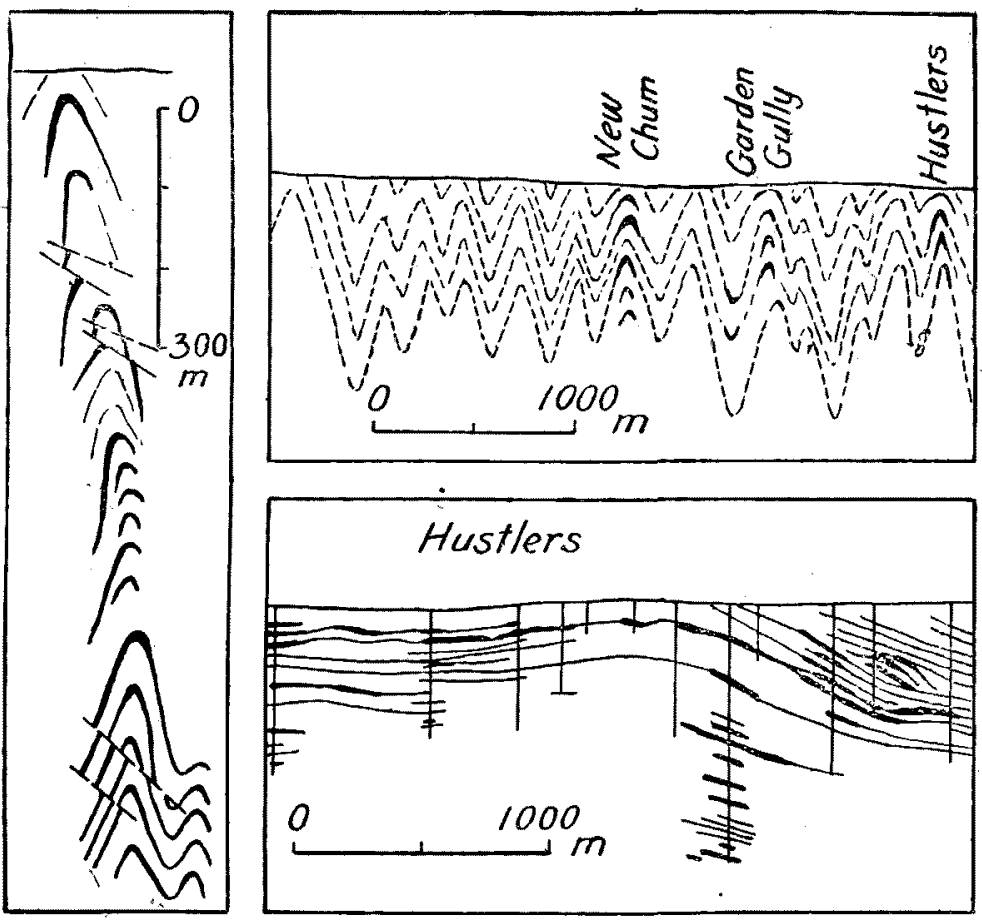

Pendego 碰床垂直斷面阔

(Herman 氏による)

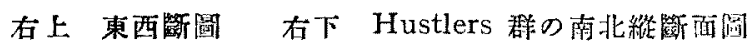
左同上東醉橫断面圆，

飞多數上下に重存り合つて生じ，Hustlers 背斜の一部籍では，同一堅坑中 少くとも，20 枚以上を數へられるものがある。その上てれら性數润の隣接 背科帶に亘つて並び存し, Bendigo て於ける New Chum, Garden Gully， Hustlers はその代表的のものであり，背斜の延長に沿ふた從斷面では，総 


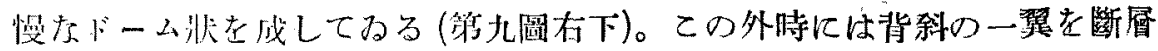

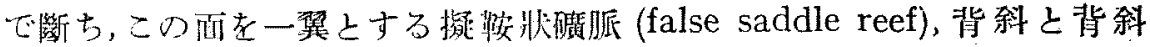

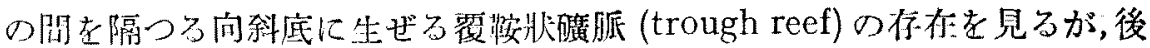
者は大䙺模なものがない。碩石は主に 第拾圖

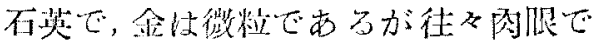

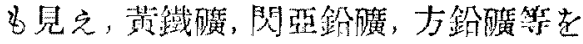

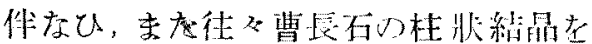
㫕ろこ上があう。

Ballarat ${ }^{1 /}$ 碩床は Melbourne の西北 阿 IIO料, Bendigo o南々河約 I 20 䉼 に位する。これまたまとして骨陶紀砂 㞸及び粘板崔から成る地域で，乘方凡

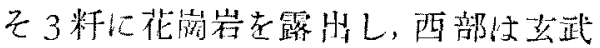
岩に被怯狄てるる。磺脈は主として3 群に分水, Ballarat West, Ballarat East 及び後者の北方め Little Bendigoこれに屬する。このうち I.ittle

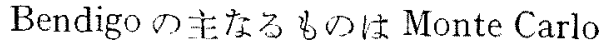

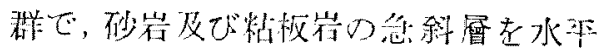
に近く横切名多数心不英脈上り战り，

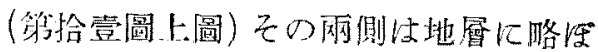

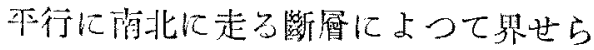
れる。Ballarat East また鱼傾斜の褶

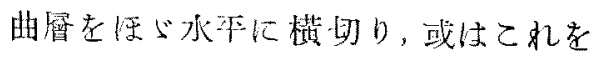
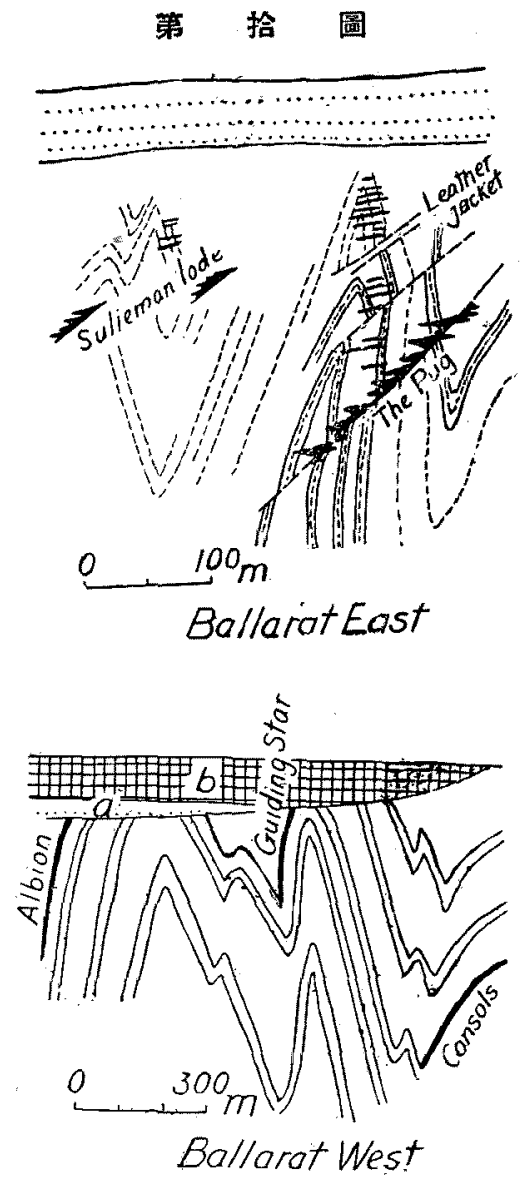

Ballarat 䃨床斷面鲝 (Herman 氏により) $\mathrm{a}$ 粘上厤 $\quad \mathrm{b}$ 玄武岩 斜めに賁双く断厤に沿つて延長し，且つその左右に泟心゙水平の多數の枝

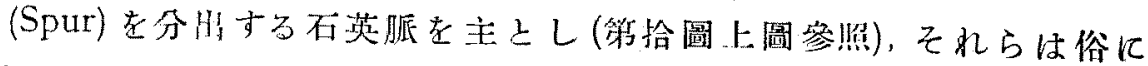

1) Maclaren 前出, 363〜367, Emmons 前出 $529 \sim 530$. 


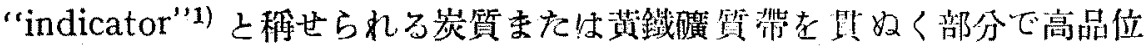
に蓬する。これらの或るものは地層であるが，一部は時に地層を㭬切る一

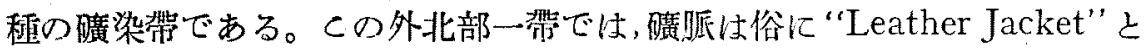
云はれる斷首粘土に沿ふ.部分でも富化してるる。

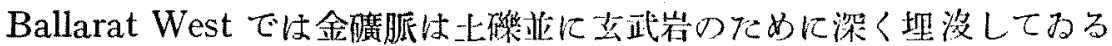

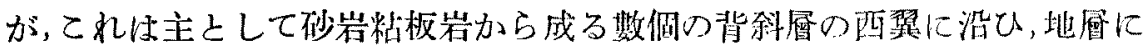

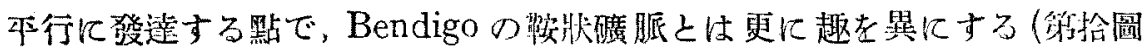
下圖參热)。

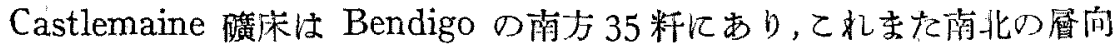
を以て，細かく褶曲した奥陶紀首が，東北側から花厥岩類の迸入を受けた部 分にあり，溗床は Bendigo, Ballarat 网地の諸型式に富み，次の請颣老包 含する。
a 普通の裂鐻充㯖礦脈
b 鞍狀碃脈
b 断層磺脈 (不規則)
d Spurs (地詹老横切万不規則脈)

Daylesford 磺床 Ballarat の北東 40 䉼に位し, 烈しく褶曲した奥陶紀砂 岩粘板岩の急斜帶在科め汇横切る多數の石英脈上り成ることBallarat Eastの一部に類する。

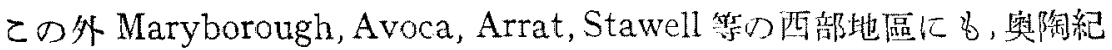
層中前記飞類する售磺床あり，また遥かに東力に離狆，Melbourne 東力 I50 籸の Gippsland (Walhalla, Wood's Point 等) その遥か北方 Beechworth 地方の Gaffnay's Creek 等には，急傾斜せる舆㓡紀下部屏老㲊理 に平行に貫ぬく石英雲母閃綠岩を横切りて，榒状磺脈 (Ladder vein) 老成 す使ぐ水平の多數の石英脈があり，㞸脈の厚さ最大 60 米，簧脈の厚さ $0.3 \sim 3$ 米に逹する (第拾壹圖下圖)。

砂金礦床 Victoria 州過古の座金の大部分は，主として砂金からである。 これに現在の河床を主とする淺在砂金と、過去の地脣または火山岩類に

1) T. A. Rickard, Am. Inst. Ming. Eng. Vol. 30, 1004 1019, 1901 , 


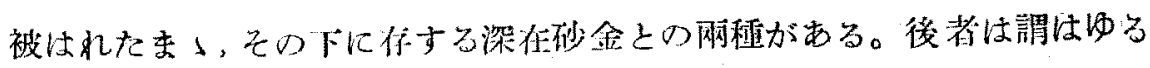

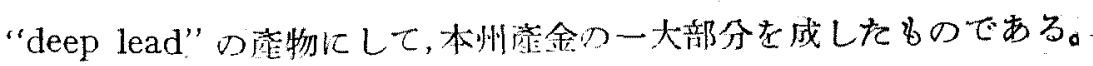

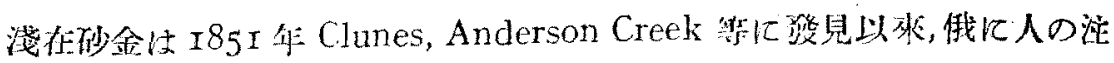
意惹き, Ballarat $の$ 南隣 Buninyong 老始め, Pleasant Creek, Ararat, Avoca, Tarrangower, Bendigo, Beechworth 等に次《に多量に發見せら

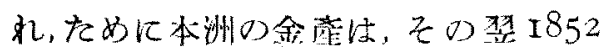
第拾 壹 圖

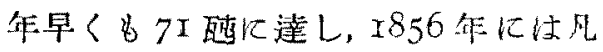

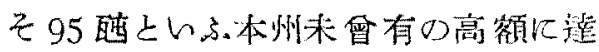
したが，1870年頃までには，その大部 分は掘り盡された。しかしその後名各 地儿屡父發見学，Tarrangower几近 い Poseidon 砂金地の如き，I906 年に 至つて一時に多數の金塊在产し，また 近年は大規模大深渫作菜に上り，嵹㭙

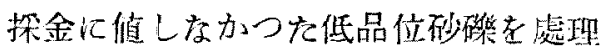
してわる。

こ扎らの砂金の源老成すのは，主上 して既述D奥陶紀層中心金磺脈て，之 机らは少くとも中部解新世に於て早く

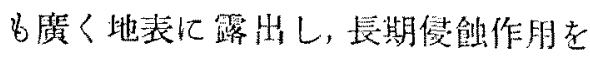
受け，それらを異好く當時す河底儿砂 金亡なつて集归したが，その地體の沈

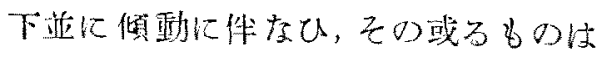
泥土の底に盐多れ，且つ或亏为のは数
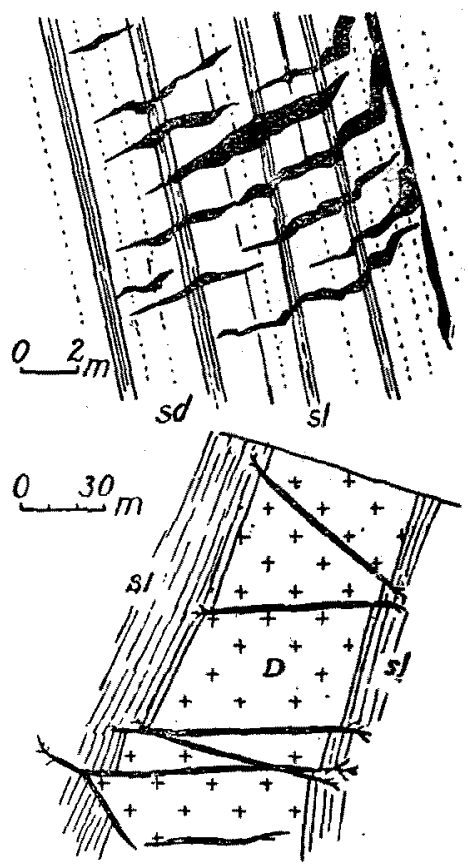

上バララット余山メトロポリタン 嘫枺

下ビーチウオース金山 Morning Star 嘫床

(Maclaren 氏による)

Sl 粘板岩 Sd 砂岩 D 阴綠岩

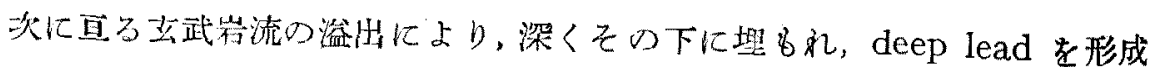
した。乙れらの大部分また現在の分水嶺を中心にして, 北或は南に下り， 西加順に Stawell, Avoca, Loddon, Campaspa, Goulburn, Ovens, 
Murry 等は北流し, Pitfield, Ballarat, Dargo 等は南沉向ひ，その或るも

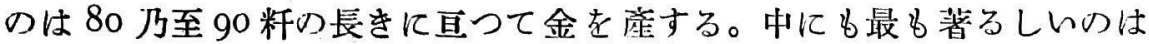
Ballarat のすぐ北方山背から北流するLoddon Lead で, その上流 Madam

第 拾 氮 圖
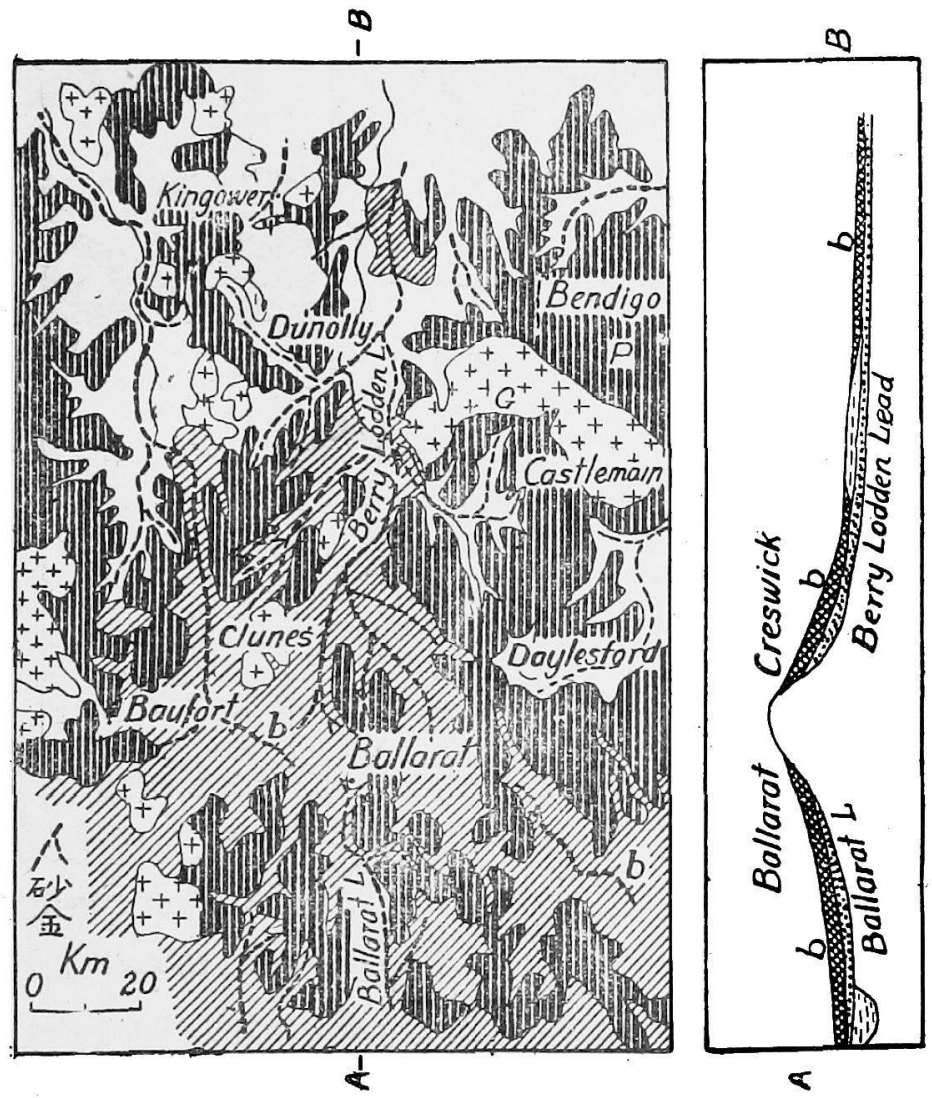

ヴィクトリヤ州深在杪金帶の分布

(Maclaren 氏による)

$\mathrm{P}$ 古生層 $\mathrm{G}$ 花崗岩類 $\mathrm{b}$ 去武岩

Berry Leadでは, 長さI.8料,幅 I40 米の間から,實に I50 萬磅といふ。多量 の金を產してねる。

以上の如く，Victoria 州の金蕉の主なるものは砂金であつて，管ては属 
そ大金塊の商出を以て著るしく，例へば次の通である。

\begin{tabular}{|c|c|c|c|c|}
\hline 输塊名 & 鹿 地 & 發見年月 & 重量(オンス) & 洒格 (磅) \\
\hline Canadian & Ballarat & 1853 年 1 月 31 日 & 1,319 & 5,532 \\
\hline Sarah Sands & , & 1854 年 9 月 18 日 & 755 & 3,200 \\
\hline Blanche Barky & Kingower & 1857 年 8 月 27 日 & 1,743 & 6.915 \\
\hline Dunolly & Dunolly & 1857 年 & 1,364 & 5,500 \\
\hline Welcome & Ballarat & 1858 年 6 月 15 日 & 2,195 & 9,325 \\
\hline Welcome Stranger & Moliagul & 1869 年 2 月 5 日 & 2,516 & 9,553 \\
\hline & Poseidon & 1906 作 12 月 18 日 & 953 & 2,878 \\
\hline
\end{tabular}

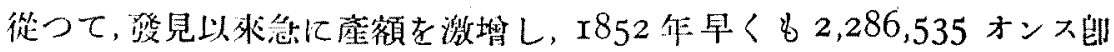
ち 7I 赸に達し，I86I 年に至るまでは，一年 2,000,000 オン スを下ること

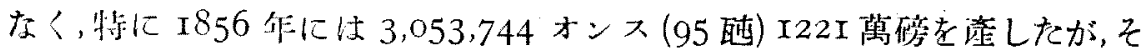

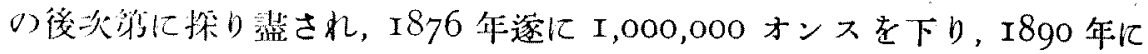
は更に57600オンスに下つた。その後磺脈の開没により，再び座額を漸埼 しI890 年には772,290オンスに上り，當時の最当なる喾地は

$\begin{array}{lrlr}\text { Bendigo } & 22 \mathrm{I}, \mathrm{I} 87 \text { オンス } & \text { Ballarat } & \mathrm{I} 64,065 \text { オンス } \\ \text { Bee:chworth } & \mathrm{I} 34,8 \mathrm{I} 2 \text { オンス } & \text { Castlemaine } 99,386 \text { オンス } \\ \text { Gippsland } & 97, \mathrm{I} 80 \text { オンス } & \text { Maryborough 80,267 オンス }\end{array}$

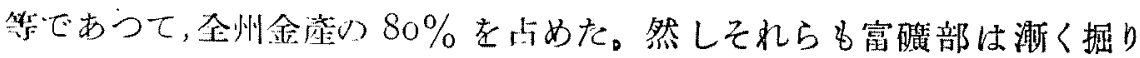
悲され，I924 年には Victoria 全洲で 67,I67 オンス，I930 年には 24,II9 オンスの (0.75 酗) 金在するに過ぎなかつた。然るにその後金價の騰点 その他に上つて復活し，1935 年には87,609 オンス，I938 年には I44,243 オンスに上り，その一部分は低然しして Bendigo 金山の座にか」り，一部 は洗金船による。即ち同年 Bendigoでは Central Nell Gwynne 會社の 6.I09 オンス, Deborah 會䣓の 5,260オンス在始め, 總計 28,8 II オンス

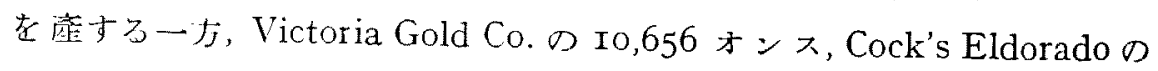

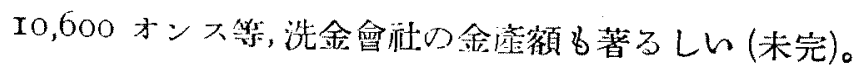

